DOI: $\square$ https://doi.org/10.15407/techned2020.06.077

\title{
ANALYTICAL AND CFD-CALCULATION OF THE HEAT CONDITION OF FOIL WINDINGS OF OIL DISTRIBUTING TRANSFORMERS
}

\author{
Journal \\ Publisher \\ ISSN \\ Issue
}

Pages
Tekhnichna elektrodynamika

Institute of Electrodynamics National Academy of Science of Ukraine 1607-7970 (print), 2218-1903 (online)

No 6, 2020 (November/December)

$77-86$

\author{
Authors \\ V.F. Ivankov' ${ }^{1}$, A.V. Basova1, I.V. Khimjk ${ }^{2}$ \\ 1- PrJSC «ZTR», \\ Dniprovske shose, 3, Zaporizhya, 69600, Ukraine \\ 2- Institute of Electrodynamics of National Academy of Sciences of Ukraine, \\ Peremohy av., 56, Kyiv, 03057, Ukraine, \\ e-mail: vsi1943@ukr.net
}

\begin{abstract}
An analytical method of calculating the thermal condition of foil windings of lower voltage oil distribution transformers has been developed. At known oil temperatures in the tank, this technique provides the identification of heat-recoil ratios on winding surfaces, taking into account their design features and heat loads, as well as calculating the excess esexcesses of the average temperature of the winding and its most heated point above the oil and over the cooling environment. In order to calculate the excess temperature of the winding over the oil by the method of separating variables using the final cosinus-conversion Fourier obtained the solution of the edge problem for the Poisson equation with heterogeneous boundary conditions on the surfaces of the rectangular section winding with anisotropic properties and with its uneven distribution of losses. In addition, an alternative approach has been developed to determine the thermal state of an axisymmetric transformer model by numerical CFD modeling of the system of equations of motion and continuity of the Navier-Stokes coolant. This allows you to obtain the distribution of the oil velocity field and absolute temperatures, both of the oil in the tank, and of the foil and ball windings of the transformer using the minimum empirical data on the physical properties of the oil and the heat transfer of the tanks. The methods are verified by known experimental data for transformers TM-1000/35 and TM-630/10. References 11,
\end{abstract}


figures 4 , tables 2 .

Key words: transformers distributive, windings, foil, oily cooling, heat, CFD-modeling.

Received: 04.03.2020

Accepted: 10.08 .2020

Published: 21.10.2020

\section{References}

1. Biki M.A. Power transformer design. Basic parameter calculations. Moskva: Znak, 2013. 612

p. (Rus).

2. Bormosov V.A., Kostousova M.N., Petrenko A.F., Smolskaia N.E Prospects and state of development of distribution transformers of mass series. Information portal

"TRANSFORMatory", 2004. 22 p. (Rus).

URL: https://transform.ru/articles/html/03project/a000001.article (accessed at 19.02.2020)

3. IEC 60076-2. Power transformers - Part 2: Temperature rise for liquid-immersed transformers, 2011. $100 \mathrm{p}$.

4. IEC 60076-7. Power transformers - Part 7: Loading guide for oil-immersed transformers, 2017. 89 p.

5. Voyevodin I.D., Gitin Yu.S., Mikhaylovskiy Yu.A., Shchukina I.I. Guidance document RD16 452-88. Power oil transformers with cooling systems $M$ and D. Thermal calculation of windings. Zaporozhye: VIT. 1988. 28 p. (Rus).

6. Mikhailovskii A., Ivanova Z.F., Serebritskaia E.A. Calculation method OAX 682.064. Method for calculating oil heating in power transformers with corrugated tanks with a capacity of 100 to 2500 kVA. Zaporozh'ye: VIT. 1995. 8 p. (Rus).

7. Hrihorov I. B., Stepenko O. N. Electromagnetic research of distribution transformers with LV windings made of aluminum tape. Elektrotekhnicheskaia promyshlenost. Seriia Apparaty vysokoho napriazheniia, transformatory, silovye kondensatory

. 1982. Vyp. 9 (131). Pp. 1-4. (Rus).

8. Voyevodina Ye.I., Grigorov I.B., Ivankov V.F., Stepenko O.N. Calculation of temperature rise in low voltage foil windings of distribution transformers. Tekhnicheskaya elektrodinamika. 1984. No 1. Pp. 32-34. (Rus).

9. Ivankov V.F., Basova A.V., Khimiuk I.V. Methods for modeling transformers and reactors. K.: Nash format, 2017. 490 p. (Ukr).

10. Kennedy S.P., Gordner T., Berube J.N., Ringlee R., Aubin J. Hot stop studies for sheet wound transformer windings. URL: http://neoptix.com/literature/2013-04 doble paper final.pdf 
(accessed at 19.02.2020)

11. Stulov A.S. Development of combined models and methods of thermal analysis in CAD for distribution transformers: author. dis. ... Cand. tech. sciences 05.13.12. Ivanovskiy GEU. Ivanovo. 2015. 152 p. (Rus).

PDF

(어요

This work is licensed under a Creative Commons Attribution-NonCommercial-NoDerivatives $\underline{4.0 \text { International License }}$ 